\title{
Origin of the Circumflex Branch of the Coronary Artery. A Case Report
}

\author{
Origen de la Rama Circunfleja de la Arteria Coronaria. Reporte de Caso
}

\author{
Nilton Alves
}

\begin{abstract}
ALVES, N. Origin of the circumflex branch of the coronary artery. A case report. Int. J. Morphol., 26(1):39-41, 2008.
SUMMARY: The left coronary artery usually supplies the circumflex branch which provides several atrial and ventricular branches. During a routine dissection of the coronary artery, we could detect a circumflex branch originating from the right coronary artery. This resulted in an analysis of another 59 hearts without any similar results.
\end{abstract}

KEY WORDS: Circumflex branch; Coronary artery.

\section{INTRODUCTION}

It is already known that the left coronary artery presents a bigger caliber than the right one and is preponderant, that is, its distribution area is greater. This artery supplies the circumflex branch that, on its turn, provides several atrial and ventricular branches from which the most constant is the marginal branch that goes down the left margin of the heart.

With the advent of the cardiac catheterism and the cinecoronariographia the branches and distribution of the coronary arteries became the reason of careful studies with the aim of helping in the diagnosis of coronary diseases. From this point on, certain alterations in the coronary flow could be assumed, among them, the most frequent is the origin of the circumflex branch in the right coronary artery (Page et al., 1974).

The clinical significance of this and others alterations in the coronary flow is still non-defined. There are, however, authors that report cases of stable angina, acute myocardial infarction and sudden death related with these alterations (Oliveira et al., 1988; Yamanaka \& Hobbs, 1990; Russo et al., 1991; Fernandes et al., 1992; Moreira et al., 1995; Bastos et al., 1996).

\section{CASE REPORT}

During a routine dissection of the coronary artery we could detect the circumflex branch originating from the right coronary artery (Fig. 1). Another 59 hearts were analyzed, however, another similar case could not be found. The hearts were dissected and kept in formaldehyde $10 \%$.

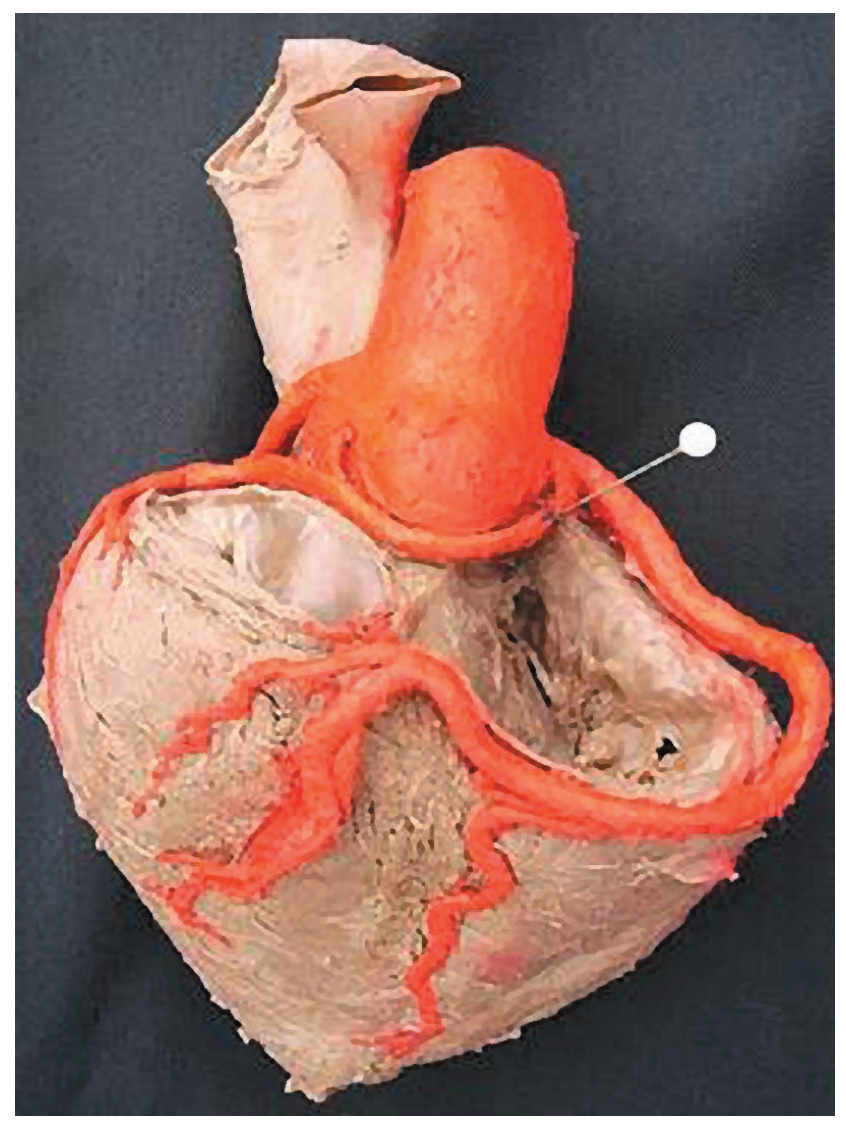

Fig. 1. Circumflex branch (arow) originating from the right coronary artery. 


\section{DISCUSSION}

Although some authors affirm that the origin of the circumflex branch on the right side has a high prevalence (Page et al.; Oliveira et al.; Effler, 1993; Cavalcanti et al., 1995), even considering such finding as an anatomic variation and not an anomaly (Effler), in our material only one case was found in which the circumflex branch was originated in the right coronary artery.

Samarendra et al. (2001) affirm that the circumflex branch of the coronary artery originated in the right side, is the most common "benign" coronary anomaly and is not considered the cause of ischemia or myocardial infarction, which confirm the conclusions of Click et al. (1989), when they claim that the most common anomaly involving the coronary artery is the one of the circumflex branch, although such anomalies are not common in adults. It must be considered however, that this condition can be present at birth, being little symptomatic during childhood, and being found incidentally through the coronary arteriography or necropsy. These same authors estimate a prevalence of approximately three in a thousand of coronary angiogram in adults showing the coronary artery anomaly. This prevalence is similar to the one found in our study and also in other authors work (Alexander \& Griffith, 1956; Page et al.; Chaitman et al., 1976; Baltaxe \& Wixson, 1977; Kimbiris et al., 1978, Cielinski et al., 1993).

Anatomic variations of the coronary arteries have been found in $0.64 \%$ to $1.55 \%$ of the patients submitted to a coronary angiography (Liberthson et al., 1974; Engel et al., 1975; Chaitman et al.; Baltaxe \& Wixson; Kimbiris et al.; Sheldon et al., 1980; Donaldson et al., 1983; Wilkins et al., 1988; Yamanaka \& Hobbs). These authors also affirm that the circumflex branch originating in the right coronary artery, is the more common anatomic variations of the coronary artery. It is, still, a low prevalence, which confirms our study.

Although it was not our goal in this work, we believe that the assumption made by some authors that the circumflex branch originating in the right coronary artery must be considered an anatomic variation and not an anomaly, must be studied more deeply to be validated.

ALVES, N. Origen de la rama circunfleja de la arteria coronaria. Reporte de caso. Int. J. Morphol., 26(1):39-41, 2008.

RESUMEN: La arteria coronaria izquierda origina la rama circunfleja la cual otorga varios ramos atriales y ventriculares. Durante una disección de rutina de la arteria coronaria, se pudo observar una rama circunfleja originándose de la arteria coronaria derecha. Del estudio efectuado en otros 59 corazones, no se encontramos resultados similares.

PALABRAS CLAVE: Rama circunfleja; Arteria coronaria.

\section{REFERENCES}

Alexander, R.W. \& Griffith, G.C. Anomalies of the coronary arteries and their clinical significance. Circulation, 14:800-5, 1956.

Baltaxe, H. A. \& Wixson, D. The incidence of congenital anomalies of the coronary arteries in the adult population. Radiology, 122:47-52, 1977.

Bastos, L. C.; Ariê, S.; Martins, J. F. C.; Almeida, R. S.; Jorge, A. C.; Kahrbek, T.; Ferreira, V. L. \& Pereira, F. L. Dupla origem do ramo descendente anterior - das coronárias esquerda e direita - associada a origem anômala à direita do ramo circunflexo. Arq. Bras. Cardiol., 67(6):407-9, 1996.

Cavalcanti, J. S.; de Lucena Oliveira, M.; Pais e Melo, A.V.
Jr; Balaban, G; de Andrade Oliveira, C. L. \& de Lucena Oliveira, E. Anatomic variations of the coronary arteries. Arq. Bras. Cardiol., 65(6):489-92, 1995.

Chaitman, B. R.; Lespérance, J.; Saltiel, J. \& Bourassa, M.G. Clinical, angiographic, and hemodynamic findings in patients with anomalous origin of the coronary arteries. Circulation, 53:122-31, 1976.

Cielinski, G.; Rapprich, B. \& Kober, G. Coronary anomalies: incidence and importance. Clin. Cardiol., 16:711-5, 1993.

Click, R.L.; Holmes Jr., D. R.; Vlietstra, R. E.; Kosinski, A.S. \& Kronmal, R.A. Anomalous coronary arteries: location, degree of atherosclerosis and effect on survival 
- a report from the coronary artery surgery study. $J$. Am. Coll. Cardiol., 13(3):531-7, 1989.

Donaldson, R. M.; Raphael, M.; Radley-Smith, R.; Yacoub, M. H. \& Ross, D. N. Angiographic identification of primary coronary anomalies causing impaired myocardial perfusion. Cathet. Cardiovasc. Diagn., 9:237-49, 1983.

Effler, D. R. Introduction. In: Favaloro, RG. Surgical treatment of coronary artery. Am. Heart J., 8:80, 1993.

Engel, H. J.; Torris, C. \& Page, H. L. Jr.; Major variations in anatomical origin of the coronary arteries: angiographic observations in 4.250 patients without associated congenital hearth disease. Cathet. Cardiovasc. Diagn., 1:157-69, 1975.

Fernandes, E. D.; Kadivar, H.; Halman, G. L.; Reul, G. J.; Ott, D.A. \& Cooley, D.A. Congenital malformations of the coronary arteries: the Texas Heart Institute Experience. Thorac Surg., 54:732-40, 1992.

Kimbiris, D.; Iskandrian, A. S.; Segal, B. L. \& Bemis, C. E. Anomalous aortic origin of coronary arteries. Circulation, 58:606-15, 1978.

Liberthson, R. R.; Dinsmore, R. E. \& Bharati, S. Aberrant coronary artery origin from the aorta: diagnosis and clinical significance. Circulation, 50:774-9, 1974.

Moreira, A. E. L. C.; Medeiros, G. C. X.; Ladeira, R. M. G.; Beltrão, P. E. A. \& Pimenta, J. Origem anômala da artéria circunflexa e espasmo coronariano. Arq. Bras. Cardiol., 64:341-3, 1995.

Oliveira, S. F.; Ramires, J. A. F.; Meneguetti, J. C.; Camargo, E.; Ratti, M.A. N.; Lopes, A. A. B.; Bellotti, G. \& Pileggi, F. Anomalias congênitas de artérias coronárias: possível causa de insuficiência coronária. Arq. Brás. Cardiol., 50(5):285-91,1988.

Page, H. L. Jr.; Engel, H. J.; Campbell, W. B. \& Thomas, C. S. Jr. Anomalous origin of the left circumflex coronary artery: recognition, angiographic demonstration and clinical significance. Circulation, 50:768-73, 1974.

Russo, G.; Tamburino, C.; Licciardello, G.; Calvi, V. \& Giuffrida, G. Isolated anomalous origin of the left anterior descending coronary artery from the right coronary artery with angina pectoris. Eur. Heart J., 12:558-60, 1991.
Samarendra, P.; Kumari, S.; Hafeez, M.; Vasavada, B.C. \& Sacchi, T.J. Anomalous circumflex coronary artery: benign or predisposed to selective atherosclerosis. Angiology, 52(8):521-6, 2001.

Sheldon, W.C.; Hobbs, R. E.; Millit, D.; Raghavan, P.V. \& Moodie, D.S. Congenital variations of coronary artery anatomy. Cleve Clin. Q., 47:126-30, 1980.

Wilkins, C. E.; Betancourt, B.; Mathur, V. S.; Massumi, A.; de Castro, C. M.; Garcia, E. \& Hall, R. J. Coronary artery anomalies: a review of more than 10.000 patients from the Clayton Cardiovascular Laboratories. Tex. Heart. Inst. J., 15:166-73, 1988.

Yamanaka, O. \& Hobbs, R.E. Coronary anomalies in 126,595 patients undergoing coronary arteriography. Cathet. Cardiovasc. Diagn., 21:28-40, 1990.

Correspondence to:

Prof. Dr. Nilton Alves

Rua Humaitá, 1680

CEP: 14.801-903

Araraquara, São Paulo

BRASIL

Email: niltonnalves@hotmail.com

Received: 05-10-2007

Accepted: 10-12-2007 
